\title{
A Bihari gyermekmondókák vallatása
}

A Bihari gyermekmondókák (Faragó-Fábián 1982) az egyik leggazdagabb és szövegtípusok szerint leginkább strukturált gyermekfolklór-kiadványunk. Ihlető közege a történelmi Bihar vármegye (népiesen: Biharország) és sok tekintetben Arany János nagyszalontai, az irodalmi nyelvbe átáramló nyelvi hatása. A történelmi vármegye nagyobbik része a trianoni döntés nyomán Romániához került. Kiemelendő és külön értékelendő, hogy a bihari gyermekmondókák gyüjtése 1967-1976 között 34 településen, a kötet megszerkesztése és az anyag közzététele 1982-ben a romániai magyarság különösen nehéz időszakában valósult meg.

\section{A bihari gyưjtés és előzményei: Arany, Viski, a Szendreyek és Kodály}

A magyar folklórlingvisztikai, másként népköltészeti-nyelvi gyüjtés fontos és kisugárzó kiindulópontjának tekinthetjük a Bihar megyei Nagyszalontát, nyilvánvalóan Arany János Toldija (1846) kapcsán. A Toldi sikere, népszerüsége, nyelve többek kíváncsiságát fölkeltette a forrás földerítésére, kutatására. Az egész Arany család, de mindenekelőtt fia, Arany László érdeklődése is a népköltészet felé fordult. 1862ben jelent meg a 19. századi magyar folklórgyüjtemények legnagyobb hatású kiadványa, Arany László Eredeti népmesék címü kötete. A második világháború után a Magyar Tudományos Akadémia pincéjéböl elökerültek olyan kéziratok, amelyek e kötet alapját képezhették. Kiderült, hogy a szövegeket Arany Jánosné Ercsey Julianna és gyermekei, Arany Julianna és Arany László jegyezték le valószínüleg az 1850 és1862 közötti időszakban (Domokos-Gulyás 2018; Balázs 2019). A,„családi” indíttatás után, az Arany-kultusz folyományaként a 20. század elején elkezdődött a néprajzi-folklorisztikai kutatás. Először Viski Károly néprajztudós személyében, aki a nagyszalontai gimnáziumban tanított 1909 és 1912 között. Ezt írta ennek kapcsán: „sokat foglalkoztam Arany költői nyelvével s nyelvének, költészetének Szalontával való kapcsolatával. Tanítványaimat gyüjtőmunkára képeztem ki, e kezdeményezés eredményei - távozásom után - ottani tanár utódom, Szendrey Zsigmond tevékenységében jelentkeztek" (Viski 1941). Szalontai munkálkodásának betetözése az Arany népe néprajzi kismonográfia (Viski 1919), amely a későbbi nagyszalontai Arany-múzeumnak a megalapozását szolgálta. Viskit Szendrey Zsigmond néprajzkutató követte, aki 1912 és 1918 között tanított a nagyszalontai gimnáziumban. Öt ugyancsak megfogta a hely szelleme, és a finnugrisztikai érdeklődése itt fordult az Arany-hagyományok és a néprajz felé. A fordulatot Dánielisz Endre ezzel magyarázza:

„Szendrey Zsigmond tekervényes vargabetűk után, harminchárom évesen érkezett a bihari parasztváros új főgimnáziumának magyar-latin katedrájára. Korábbi finnugor nyelvészkedése egyáltalán nem jelezte érdeklődésének a néprajztudomány elméleti és gyakorlati kérdései felé való fordulását. Mégis, miként magyarázható, hogy a letelepedését követő hetekben, hónapokban már a helyi hagyományok összegyüjtésének, megörökítésének széles körü mozgalmát irányítja? Berze Nagy János a még teljessé- 
gében pompázó hajdúvárosi népi kultúrát említette az életutat eldöntő okként barátja halálára írott nekrológjában: »Szendrey Zsigmond szakadatlan munkában telő tevékenysége nagyszalontai tanárkodása idején indul meg. Bizonyára nem véletlen, hogy a népi és történelmi hagyományokat lehelő hely s a szalontai magyar élet megragadja az ifjú tanár figyelmét, s azt a hagyományokra irányítja, hogy azoktól többé soha el ne szakadhasson... Szendrey Zsigmond élete ettől fogva a magyar néprajznak van eljegyezve s alig van azóta az Ethnographiának száma, amelyből kisebb vagy nagyobb dolgozata hiányoznék. « Szerintem az Aranyt is bủvkörébe vonó »beszédes monda«, a szalontai nép tiszta, ép és erőteljes nyelve, s az emberek hétköznapi életét irányító, megszépítő hagyomány és szokás alapot és kifutási lehetőséget nyújtott a ráérző kutatónak, azonban a döntő okot én másutt keresem” (Dánielisz 1981: 202-3).

Dánielisz Endre azonban a hely szellemén túl a korszellemben is keresi a magyarázatot, és erre bizonyítékot is talált.

\begin{abstract}
„A tízes évek eleje fordulópontot jelentett az értelmiségiek legjobbjainak a népélet és a népi kultúra iránti magatartásában. Tanárok és diákok, falusi papok és tanítók áldozták szabad idejüket a népi hagyományok lejegyzésére. A mozgalom esze-lelke Sebestyén Gyula. A nagy szervező figyelme - föltehetően még Viski idejében (s talán épp neki köszönhetően) - Szalonta felé fordult, s az érkező Szendreynek már csak a reá váró és egyéniségéhez, tudományos alkatához illő szerepet kellett betöltenie. Véleményemet igazolja az a tény is, hogy néhány héttel Szendrey jövetele után megalakították a Folklore Fellows (Néphagyománykutató Nemzetközi Tudományos Szövetség) nagyszalontai fiókját. Vezetőjévé a frissiben érkezett irodalomtanárt jelölték, akit Tatár Balázs, a gimnázium igazgatója és Debreczeni István helybeli református lelkész részesített erkölcsi, eszmei támogatásban. Ök egyébként az immár három évtizede müködő Arany Emlékegyesületnek is választmányi tagjai voltak. Így válik még érthetőbbé az a tény, hogy az egyesület vezetősége épp ekkor, 1912-ben határozta meg az elkövetkezendő időkre szóló célkitüzéseit, s többek között kimondta: »Az egész világon megindult mozgalom: a néphagyomány emlékeinek összegyüjtése (Folklore Fellows) hazánkban éppen mostanában kezd nagyobb arányokat ölteni, midőn az ország különböző részein, iskolák és egyesületek támogatásával, vidéki gyüjtőszövetségeket alakítanak. Ilyen szervezését a központ nálunk is tervbe vette s alkalmasabb talaj alig lehetne más, mint Nagyszalonta... E munkát megindítani, vezetni, vagy legalább támogatni egyesületünknek leend méltó feladata...«A felsorakoztatott tények nyomán szükségszerü következményként fogadhatjuk el, hogy az egykori finnugor nyelvész érdeklödési köre éppen Nagyszalontán és 1912 után váltott át a folklór irányába" (Dánielisz 1981: 203-4).
\end{abstract}

Ráadásul Szendrey Zsigmond fiára, Ákosra is nagy hatással volt tanár édesapja, a nagyszalontai lét, a népköltészet és természetesen Arany János. A Magyar Népköltési Gyüjtemény sorozat Nagyszalontai gyüjtés Gyermekjáték fejezete (Szendrey Zs. 1924: 164-78) a szerkesztő, Szendrey Zsigmond akkor II. osztályos kisfiának, Szendrey Ákosnak, a későbbi jeles folkloristának a gyüjtése, ahogy a kötet Sebestyén Gyulától írt előszavából kiderül:

„Fia, a kis II. osztályos Ákos, annyira föllelkesedett a diákoknak szónokoló budapesti úr [valószínüleg Sebestyén Gyula, B. G.] tanításain, a kezébe nyomott Tájékozató uta- 
sításain és az ifjúsági pályadíjak kinyomtatott lajtstromának csábító ígéretein, hogy a munkából részt kért édes atyjától. A pályázatra a parányi gyűjtő szolgáltatta be a legértékesebb gyüjtemények egyikét. Az okos apa, ismerve fia rátermettségét, olyan teret jelölt ki számára, amelyen egy ilyen kis fiú csakugyan sikeresebben tud gyüjteni, mint akár az apja, vagy más öreg folklorista. [...] A kis Szendrey »dajkarímek, gyermekdalok, játékok és játékmondókák « gyüjtésére vállalkozott. Nyakába vette tehát Nagyszalonta minden játékterét $\mathrm{s}$ üres óráiban a céltudatos kutató éberségével eljátszatott és elmondatott, aztán megtanult és pontosan lejegyzett minden forgalomban lévő vagy már feledésnek indult rigmust és játékot. A készséggel segédkező játszótársak természetesen egész Nagyszalontát felhajszolták s a kis gyüjtő gyüjteménye elvégre teljessé lett" (Sebestyén 1924: XIII).

Csakhogy a Nagyszalontai gyüjtés társszerkesztője - Szendrey Zsigmond mellett - Kodály Zoltán volt, aki ugyancsak megfordult Nagyszalontán (SzendreyKodály 1924). Állítólag Sebestyén Gyula ötlete volt, hogy az Arany-centenáriumra készülődő Nagyszalontán népzenei gyüjtést folytasson: „Mivel Szalonta nagy szülöttjének, Arany Jánosnak csodálatos ritmusérzéke a népköltésben gyökerezett, 1916ban felkértem kitünő zene-folkloristánkat, Kodály Zoltán zeneakadémiai tanárt, hogy a diákok és tanáraik által gyüjtött szövegek dallamait is jegyezze le, s kötetünk kiegészítéséül szerkesszen egy zenei függeléket." (N. Tóth 2001). Kodály Zoltán így emlékezett: „A közlendő dallamokra nézve azt az irányítást kaptam, hogy lehetőleg azt válogassam össze, amit Arany János ismerhetett.” Kodály Zoltán huszonhét füzetnyi szöveg áttanulmányozása után 1916-ban három hetet töltött Nagyszalontán, és - némi nehézségek árán - igyekezett összegyüjteni a dallamokat (N. Tóth 2001).

A bihari, nagyszalontai folklórhagyományok egyenes vonala tehát: Arany János és családja (Arany László), Viski Károly, Szendrey Zsigmond, Szendrey Ákos és Kodály Zoltán. A nagyszalontai folklórgyüjtések, kiadványok hatással voltak az 1970-es években indult újabb nagy közösségi vállalkozásra, a gyermekfolklór, azon belül a gyermekmondóka-gyüjtésre. A nagyváradi Fáklya címü folyóirat 1976-os felhívására (a romániai) Bihar megye 34 településéről 169 pályázat és 7000 gyermekmondóka-változat érkezett. Az 1979-ben megismételt felhívásra már csaknem 10000 mondóka gyült össze. A Bihari gyermekmondókák címü kötetben foglalt anyag végső száma: 70 helységből 10915 mondóka (egészen pontosan mondókák és variánsaik). A legnagyobb számban a következő településekről érkezett anyag: Cséhtelek, Érbogyoszló, Érmihályfalva, Margitta, Nagyszalonta, Nagyvárad, Szalacs, Tenke. Nagyszalontáról 17 gyüjtésből 625 mondóka került a kötetbe. Csak összehasonlításként: Nagyváradon 44 gyüjtésböl 839 mondóka lett beküldve. Ahogy a kötet bevezetőjében megjegyzik: „Aligha akad Erdélyben még egy olyan megye, ahonnan bármelyik magyar népköltési müfajt ily tömegben sikerült mostanáig összegyüjteni és archívumban tárolni” (Faragó-Fábián 1982: 11). Fontos felhívni a figyelmet arra, hogy a Bihari gyermekmondókák folklórlingvisztikai szempontból az egyik legteljesebb és legjobban strukturált gyermekmondóka-anyag. Ennek bemutatása a mostani tanulmány tárgya. 


\section{A gyermekmondóka: kötött, ritmikus (zenei) szöveg}

Kodály Zoltán folklórlingvisztikai gondolkodására hatással volt a nagyszalontai gyüjtés. Gyermekjátékok címmel jelent meg a Magyar Népzene Tára sorozat I. kötete, amelynek előszavát Kodály írta. Kodály több munkájában is foglalkozott zene és nyelv genetikus kapcsolatával, illetve a zene szerepével a gyermeki fejlődésben. Fontos észrevétele, amely addig nem volt ennyire egyértelmű, és elsőre furcsának is tünik, hogy a gyermekfolklór a folklór legarchaikusabb rétege: „Minden ország kutatója egyetért abban, hogy a gyermekhagyomány örzi a legrégibb elemeit a néphagyománynak" (Kodály 1993: 220). A különbözö kulturális jelenségek közös gyökerüek: „Kutatóink eddig nem ismerték fel a gyermekdal jelentőségét. Gyermekrajz, gyermeknyelv, párhuzamos gyermekpsychológia. [...] Gyermekhagyomány - gyermekalkotás..." (Kodály 1993: 223). A gyermekfolklórban megőrződtek a felnőttvilágból kiesett jelenségek, például: „Gyermekjátékká süllyedt népszokás, vallásos (szövegek), táncok, táncterminusok" (Kodály 1993: 219). A gyermekfolklórban tanulmányozható az ősi szinkretizmus, az a jelenség, amelyben még nem váltak szét a különböző kulturális és tudatformák: „A gyermek nem zenél: osztatlan egység az ének, tánc, játék" (Kodály 1993: 226). A gyermekfolklórban tetten érhető az alkotás keletkezése, átadása, átalakulása: „A népdal psychológiájának tanulmányozására legalkalmasabb a gyermekdal, mert itt mintegy »in statu nascendi« tárul elénk. Szinte előttünk folyik le a bomlás, új alakulás, romlás, bővülés, kopás, zsugorodás, új változat születése; látjuk miből mi alakul. Ösrégi és vadonatúj elemek megférnek, vegyülnek, majd szétválnak" (Kodály 1993: 219). A folklórmüködés (és nyelvkeletkezés) egyik alapvető módszere az ismétlés: „A kis motívumok változatlan ismétlése az egyik véglet. A gyermek egyes szavakat is szeret vég nélkül ismételni...” (Kodály 1993: 225). Ahogy a nyelvkeletkezés esetében is gondoljuk és modellezzük, ugyanúgy történik minden kulturális jelenséggel: az egyedfejlődés gyorsítva megismétli a fajfejlődés főbb mozzanatait: „A gyermek életében újra lejátszódik a múlt. Mikor már túl van a határozatlan hangmagasságon, 2-3 hangnyi dallamaival a primitív népek fejlettségi fokán halad keresztül. Majd bővül hangkészlete, finomul ritmusa, hallása. Mire felnő, eléri környezete felnőttjeit, a fejlődés új útja nyílik meg előtte: tanulj fiam, légy okosabb apádnál...” (Kodály 1993: 226). Kodály szerint a gyermekmondóka „a gyermekdal - rendszerint dallamtalan - oldalhajtása” (Faragó-Fábián 1982: 13). A gyermek világában mindenkinek feltünik a ritmus szerepe, ráadásul a mozgáshoz való kötöttsége. Azt is megállapítja, hogy a gyermekmondókáknak a felnőttek folklórjában is megvan a folytatásuk vagy megfelelőjük (Faragó-Fábián 1982: 174). Részösszefoglalásként tegyük hozzá a kötet szerkesztőinek előszavából Goethe gondolatát: „A gyermek mindenből mindent tud csinálni...” (Faragó-Fábián 1982: 18).

A mondóka az emberi élet folyamatos kísérőjelensége, kialakulása a nyelvhez köthető: ritmikus ismétlés, és Fónagy Iván termékeny kifejezésével: élvezetes struktúra, örömalakzat (Fónagy 1990: 36). Azt már én teszem hozzá, hogy az öröm genetikusan kódolt (magunkkal hozott) és sajátos (egyébként nemcsak emberi!) ösztönzőelem. Valamennyi alapszükségletünk kielégítését örömérzés követi, csakúgy, mint az alapszükségletekre ráépülő, azokból továbbfejlesztett kulturális szükségle- 
teket. Ebből fakadóan: az öröm az életmüködés alapvető mozgatója. És mindegyik esetében fölfedezhető a ritmikus ismétlés (sport, tanulás, étkezés, szeretkezés, szokások). Az ember önkéntelenül, spontán módon és tudat alatt is gyakorolja a ritmust, amelynek nyelvi formája lehet az ismétlés (hang-, szó-, mondat- és gondolatismétlés) és ennek számos variánsa (alliteráció, duplikáció, figura etimologica, gradáció, halmozás, iteráció, kiazmus, paralellizmus, reduplikáció, refrén, rím, szinonímia) (Szathmári 2008: 322); esetünkben leginkább a rigmus. A gyermeklét teli van ilyen önkéntelen rigmusokkal, majd ezeket jórészt elfelejtjük, és a gyermek vagy unoka születése hívja elő ismét őket. De a felnőtt életben is rengeteg ilyen vagy ehhez hasonló rigmust használunk.

(1) Családi rigmusok: Mi lesz ma ebédre? Édes, kedves krumplileves. - Ki lesz ma a Dani? Ki fogja a szemetet lehordani (saját gyüjtés).

(2) Népies, rigmusos helyzetmondatok: Mit nézö'? Nem vagy te intéző?; Ne nézzé"! Kérdezzé’; Elnézést, szabad egy mellnézést?; Falu végén templom, hogy bemegyek-e, nem t'om!; Az a lényeg, hogy tapadjon a bélyeg... (saját gyüjtés).

(3) Táncrigmusok (csujogatók): Jaj de sáros ez az út, / Vót szeretöm, de megunt; Vót szeretöm tizenhat is, Most jó lenne még egy vak is (Kallós 1973: 107-8).

A rigmusban rejlö ismétlésességnek és ebből fakadó ritmusosságnak élettani alapja van: valamilyen motorikus (ütemesen visszatérö) reflex, amely sokféle tevékenységnek, elfoglaltságnak (lábrázás, rángatás, számolgatás, firkálgatás, ${ }^{1}$ mantrázás) a kiindulópontja.

\section{Strukturális megközelítés: szövegtípus, miniverzum}

A Bihari gyermekmondókák 17 tematikai egysége az emberi világ miniuniverzuma, szójátékkal élve: miniverzuma. ${ }^{2}$ Ezek a következők:

1. dajkarím; 2. időszámítás; 3. időjárás; 4. állatvilág; 5. növényvilág; 6. hangutánzók; 7. gyermekkonyha; 8. számolósdi; 9. nyelvgyakorló, nyelvtörö; 10. varázsmondóka; 11. mesemondóka; 12. csúfoló; 13. beugrató; 14. civódó; 15. játékmondóka; 16. kiolvasó, kiszámoló; 17. egyéb.

1 „Az önkéntelen firkák formai szempontból felölelik az ember foglalkozásának, érdeklődési körének, élethelyzetének, képességei megnyilvánulási területének minden ágát. Keletkezésük kutatásánál [...] figyelmet kell fordítani a mindenkor fellelhetö játék-motívumra. A játékos fantázián túl a mủvészi fantázia megnyilvánulásai is fellelhetők. [...] állíthatjuk, hogy az önkéntelen rajzolgatás nem egyéb, mint bizonyos primitív müvészi törekvéseink kiélése" (Szászi 1943: 45-6).

2 A mini és az univerzum szavakból alkotott miniverzum szót (miniversum formában is) eddig föleg a gyermekek számára létrehozott játszóházakra, programokra, illetve bányászattörténeti kiállításra használták. 
A mondókák felölelik a természeti és humanizált környezetet (növény- és állatvilágot, időjárást), a szocializációt, azaz a társadalomba való belenövést (nyelvtanulás, számtani müveletek, társas viszonyok, játék, a felnőttvilág gyermeki leképezése, pl. gyermekkonyha). Egyes típusok a nyelv- és kultúrakeletkezés korai szakaszaira emlékeztetnek. Ilyen például a hangutánzás (egyes nyelvelméletek szerint a nyelv kialakulásában a hangutánzásnak döntő szerepe volt (pl. Renan, Geiger, Darwin, Steinthal, Max Müller, Hermann Paul, Wundt stb. vö. Sommerfelt 1974: 17-27). A nyelvelsajátítás folyamatában kapnak szerepet a dajkarímek, a nyelvgyakorlók, a nyelvtörők. Ugyancsak a kezdeti kulturális formákig vezetnek vissza a varázsmondókák, a mesemondókák, sőt a számolósdik is. A gyermekmondókákból kirajzolódik egy bináris világkép: természet és társadalom, valamint a gyermeklét és felnőttlét ellentéte.

\section{Funkcionális megközelítés}

A gyermekmondókák funkciójukat tekintve a kulturális átadásban (tanulásban, gyakorlásban), lényegében a társadalmi szerepek újratermelésében kapnak kitüntető szerepet. Fontos funkciójuk a társadalmi helyzet és normák kijelölése. A mondókák többnyire játékos szituációkba illeszkednek; sok esetben a felnőttlét viselkedésformáinak utánzását, gyakorlását szolgálják. És minden esetben szórakozást jelentenek, kísérőjelenségük, céljuk pedig: az öröm.

A mondókázás ösztönös jelensége mutatja, hogy valami nagyon ősi, talán a kollektív tudatalattiba nyúló jelenségről van szó. Erre nagyon sok nyelvi jel utal. A hangutánzás a legősibb kommunikációs-nyelvi jelenség. A felnőttvilág gyermeki leképezésének játékos formája a gyermekkonyha (ehhez hasonló a szülői vagy orvosi szerep eljátszása), amelyek felkészülést is jelentenek a felnőttkor szerepeire. Ösztönös jelenség, de didaktikus hagyomány nyoma is felfedezhető a számolósdiban, valamint a nyelvgyakorlókban és talán a mesemondókákban is.

A mai társadalomban annyira érzékeny kirekesztés, az egyenlö bánásmód és egyenlő esélyek törekvésének nyoma sincs a gyermekfolklórban. A gyermeki világ, ahogy a mondókák is tükrözik, folyamatos versengést, a gyengébb legyőzését, a megszokottól, a normától való eltérés elutasítását mutatják. Ilyen mondókák például a senkit sem kímélő, szókimondó csúfolók. Két összetevővel magyarázhatjuk ezt: evolúciós védelem az eltérésekkel szemben, esetleg a gyermeki világ még a biológiai evolúció talaján áll, a kulturális evolúció fokozatos szocializációval kezdődik, amelynek során lépésröl lépésre tanulja meg a gyermek, hogy a csúfolódás, kirekesztés nem kulturált dolog. Aligha kulturált, aligha korrekt (föleg nem politikailag korrekt), de a gyermekfolklór tele van csúfolókkal: névcsúfoló, falucsúfoló, fiú- és lánycsúfoló, szamárcsúfoló, lustacsúfolók, valamiféle „hibával”, vagyis fejlődési, személyiségi sajátossággal rendelkezők csúfolásával: síró, nyafogó, kényeskedő, cifrálkodó, gőgös, hazug, pletykás, árulkodó, sugdolózó, kíváncsi, kotnyeles, részeges, szurtos, mocskos, taknyos, kövér, kopasz, foghíjas stb. Ezek egyfajta normatív, társadalmilag elfogadott értékrendre való fókuszálást, figyelemirányítást fejeznek 
ki. Vannak még a beugratók is, amelyeknek funkciója a versengés: aki szóval győzni tud (ez a retorika alapja), az társadalmilag is előnyösebb helyzetbe kerül.

A gyermekfolklór, gyermekmondókák világa egyértelmüen mutatja azt is, hogy a gyerekek kétnemüek, fiúk és lányok, és a korunkban itt-ott fölvetett nemsemleges nevelés a kollektív tudatban, folklórban kódolt hagyomány ellenében müködik.

\section{Hangutánzás, állatvilág, zoomorfizmus}

A gyermekmondókák világában föltünően gazdag, sokrétü a hangutánzás. Ez ugyancsak arra utal, hogy a gyermekfolklór sok archaizmust, közte a nyelvkeletkezés pillanatát őrzi: természetesen leginkább „újrateremtés”, „újrafelfedezés” formájában. A gyermekmondókák körében a hangutánzás formái számos szövegtípusban megjelennek. Ezek közé tartozik a természeti és emberi hangok utánzása. Például:

(1) Dajkarím: Így törik a diót: kop-kop-kop, Úgy meg a mogyorót: rop-roprop (630. Szalacs); Gyí, te csikó, Gyulára, A gyulai vásárra (1034. Ant..., Nagyszalonta... stb.).

(2) Időszámítás: Giling-galang, Szól a harang (1563. Asszonyvására... stb.).

(3) Időjárás: Csirr-csurr, csepegö, Esik, esik az eső (1673. Cséhtelek, Tóti); Liccs-loccs, locsogó, Esik esö, hull a hó (1706. Cséhtelek).

(4) Állatvilág: Tas, tas, tas, Te kis kutya ne ugass (1966. Hegyközszentmiklós); Kukurigú, Kelemen, Mit leltem a szemeten? (2047. Albis); Liba mondja, gigá-gá, Elmegyek én világgá (2087 Érkörtvélyes).

(6) Hangutánzók: harang, vonat (mozdony), kerék, hangszer, béka, háziállat, madár (fecske, vadgalamb, rigó, gerle, pacsirta, bíbic, seregély, fürj, fácán, varjú bagoly), tücsök, dongó, egér, róka, farkas(üvöltés); egyéb: sarló, kasza, cséplőgép dobja, pipaszó, gyermeksírás.

(9) Nyelvgyakorlók, nyelvtörők között a nyelvutánzók: Tón a lúd átúsz (3239. Nagyvárad).

Nagyon ősi kapcsolat, vonzás van a növény- és állatvilághoz, ennek nyelvi mutatója a bio- vagy zoomorfizmus, a növények, de még inkább az állatok megszólítása. Szép számú adat és tekintélyes szakirodalom vonatkozik a csigahívogatókra (a Bihari gyermekmondókák kötetben: 1831-1881. sz. mondókák). Például:

Csigabiga, gyere ki, /Ég a házad ideki stb. (1846. Nagyvárad).

A Csigabiga mondókával kapcsolatban filológiai-álfilológiai vita keletkezett a közösségi médiában (több éve sokan osztják-továbbítják a neten azzal, hogy az általunk ismert formában nincs értelme a szövegnek, de ha kiegészítjük, akkor igen: „Az »ég a házad ideki«-ben az »ég« igazából nem tüzet jelent, hanem az eget. Mert úgy szól, hogy: »Csiga-biga gyere ki, AZ ég a házad ideki«.” 
Küllős Imola néprajzkutató ugyanott (Marinov 2017) ellenérvek felmutatásával igyekszik megmagyarázni: ,,a csiga-bigás mondóka úgy jó, ahogy régről tudtuk, tehát »az« nélkül”. Például már 1872-es gyüjtésben is így szerepel:

„Csiga biga, nyújtsd ki szarvad ! / Jőnek a tatárok. /Sós kútba vetnek, / Hat ökörrel kihúzatnak, / Malomkővel megnyomtatnak" (Magyar Nyelvőr, 1872).

Küllős Imola szerint a fenyegetések a csigacsalogatókban nem számítanak ritkaságnak, sőt ennél durvább változatok is léteznek. Vannak persze olyan állatos mondókák is, ahol a fenyegetés helyett csak a kérés/követelés hangzik el:

„Tücsök koma, gyere ki, / Szalmaszállal húzlak ki, / Házad elött megsüllyedtem, / Hat ökröddel vontass ki!" (Kiss 2000: 13).

A mai racionalitásra törekvő logika nem képes elfogadni a szabad asszociációkat, amelyeknek vagy van valamilyen misztikus gyökerük, vagy nincs, mert egyszerüen csak nyelvi játéknak tekinthetők. Nem kell föltétlenül észszerü magyarázatot keresni arra, hogy miért csalogatják ki házából a csigát, és fenyegetik tatárokkal meg különféle kínzásokkal; meg hogy hogy lehet hat ökre a tücsöknek. A lényeg a zoomorfizmus: az állatokkal való ősi együttmüködés, beszéd (kommunikáció). (A „városi legenda” eloszlatásának leírása itt: Marinov 2017.)

\section{Halandzsaszövegek - népetimológiák - folklorizmus}

Léteznek kimondottan halandzsaszövegek, amelyeket nyelvi mintákra tudatosan tévesen hoznak létre. De léteznek rontott szövegek is, amelyek halandzsának tünnek. Mindkét fajta halandzsaszöveg hallatán az ember jelentéskereső antropológiai beállítódása miatt nyelvi kompetenciájuk segítségével igyekszik „,helyreállítani” a jelentést; ez több esetben nem helyreállítás, hanem „népetimologizálás”.

A közismert (ki)számolók állítólag számsort rejtenek (az első három példa mutatja ezt; magyar és német számsor, magyar számsor rövidítve):

Egy, kettő, három, négy, / Józsi barát hová mégy? (5580. Berettyószéplak).

Ájn, cváj, dráj, / Melyik lábod fáj? (5584. Nagyvárad).

E, ke, há, né, ö, ha, hé, nyó, ki, lit / tie, tike, tihá, tiné, tiö, tiha, tihé / tinyó, tiki, hú, / Hue, huke, huhá, huné, hü̈, / huha, huhé, hunyó (5559. Bihardiószeg...).

Egyedem, begyedem, bébicske, / Hová mész, te menyecske? (5211. Fugyivásárhely).

Egyem, begyem, / Kettö, meddö, / Három, várom, / Katona Péter / Pitty (5576. Margitta).

Eccem-peccem, pimpaláré, / Szól a rigó, rakoncáré, / Cérnára, cinegére, / Hiss ki libám a mezöre (5256. Tenke). 
Ecske-becske, bakkecske, / Terád jut a szerencse (5321. Köröstárkány).

Katona Imre ezt írja a kiolvasókról (kiszámolókról): ,jelentős része halandzsa, mely varázsmondókát, idegenből átvett számsort stb. egyaránt őrizhet” (1979: 385). Létezik ugyebár a (valamilyen változatban) mindenki által ismert kiszámoló. Ez a bihari változat:

Apa cuka, funda luka, / Funda kávé, kaman-duka, / Apa-cuk, funda-luk, / Funda kávé, kaman-duk (5736. Margitta).

Voigt Vilmos (1975: 171) egy másik változatát idézi, és megjegyzi, hogy bár országosan ismert, de „a legnehezebben magyarázható”, „legrejtélyesebb” szöveg. A 12 elemű kiolvasót nem tudja biztosan számsorhoz kötni, és megjegyzi: „Persze, lehetséges, hogy eredetileg nem számsort takar, és az értelmezése valamely váratlan felismerés fényében egyszerünek bizonyul...”. Egy grazi előadásomban (2010-ben) ismertettem ezt a véleményt, mire egy felsőőri (Oberwart) hallgatóm az előadás után azt mondta, hogy ismeri ezt a kiszámolót, szerinte elferdített német szövegröl van szó. A szöveg „megfejtése” vagy „értelmesítése”:

Apa cuka (A par cuka) $=$ Ein paar Zucker

funda luka $=$ von der Luka

Funda kávé $=$ von dem Kaffee

kaman-duka $=$ kann man doch

Szabadon magyarul: 'néhány szem cukor, Luka községből, származó kávéba, lehet még...'. Meglehet, hogy ez is csak népetimológia, jelen esetben német. Hiszen a kiszámolóban található kávé is lehet népetimológia, csak magyar (Balázs 2012). Értelmetlen szövegeink mögött egykori értelem rejtőzhet, de meglehet, hogy már eredetileg is halandzsának, mai szóval „kamuszövegnek” készültek.

A folklórszövegek vándorlására, irodalomba való átkerülésére, alakulására (folklorizmusára, neofolklorizmusára) vonatkozó példa a Bihari gyermekmondókákból ismert egyik kiszámoló:

Szél-szál, szalmaszál, / Ecki-pecki-tengerecki Pál (5374. Erdőgyarak).

Több változata ismert: szil-szál szalmaszál (5373. Érkörtvéles); egyki-betykitengerettyi Pál (5375. Erdőgyarak); icki-picki, Berecki (5376. Gálospetri). Ezt a népi mondókát használta fel Tamkó Sirató Károly több versében is, némi változtatásokkal (újvidéki származása kapcsán föltehetőleg a délvidéki folklórból vette a példát):

(1) Tengerecki Pál: / Szil, / szál, / szalmaszál! / Merre jár a Pál? (Tamkó Sirató Károly: Tengerecki hazaszáll, gyermekverskötet, 1975). ${ }^{3}$

(2) (A vers egyik változata ugyanabban a kötetben) Tengerecki hazaszáll

3 Valamint ismert a Kaláka együttes feldolgozása is. 
Szil, / szál, / szalmaszál! / Merre járt a Pál?

Merre járt a / messzivágyó / jéghegyjáró / felhőszálló / Tengerecki Pál?

Ment, amerre / szeme látott... / Bebolyongta / a világot / - s belefáradt / már.

(3) Tamkó Sirató Károly: Gyermek dal ${ }^{4}$

Szil szál / szalma szál, / fehér (mellü) testű lány, / merről késik a szeretőd, /Tengerecki Pál.

\section{Mondóka és múvészet}

Fölvethető, hogy a mondókázás alapvetően játék, ám egyben korai művészeti tevékenység. Mivel alapja az ismétlés, a rigmus, amelynek kapcsolata van számos már említett élettani jelenséggel, befejezésül hangsúlyozni szeretném: kapcsolata van a müvészettel. Hadd hozzak erre egy párhuzamot, amelyet a firkálgatás és müvészi rajz között feltételez Szászi Éva. Karl Bühlerre (1930) hivatkozik: ,,a gyermekeknél a rajz fejlődési menete 4 fázisú. Az első fázisban az össze-vissza vonalak jelennek meg, ez az írás felfedezéséhez vezet, azután jön a szkematikus díszítés, majd az ú. n. alaprajz, tehát mikor a rajzba már rendszert visz és kiépíti azt, végül az élethű kép mutatkozik. Éppúgy a firkálásnál is - megfigyelésem szerint - meg lehet találni ezt a négy fázist aszerint, hogy a firkáló személynél a rajzolgatás milyen fokban tudatos" (Szászi 1943: 46). Hasonló fázisokat, fokozatokat a szóbeli folklór, így a mondókázás esetében is feltételezhetünk, hozzátéve, hogy mindenki tud és mond mondókákat, vagyis bírja a múvészet alapjait, de nem lesz mindenkiből sem autentikus folklóralkotó, sem pedig profi müvész.

\section{SZAKIRODALOM}

Balázs Géza 2012. Ismeretlen nyelvi tájak. In: Czövek Judit - Dyekiss Virág - Szilágyi Zsolt (szerk.): Világügyelö. Tanulmányok Hoppál Mihály születésnapjára. Magyar Vallástudományi Társaság, Budapest, 490-8.

Balázs Géza 2019. Domokos Mariann - Gulyás Judit szerk.: Az Arany család mesegyüjteménye. Magyar Nyelv 115: 233-6.

4 „A 2012-ben elhunyt fotográfus, Vattay Elemér hagyatékából elökerült egy Vattaynak dedikált, harmadik Tengerecki-vers, aminek egy szerkesztett változata már korábban is ismert volt. Ennek itt az a címe, hogy »Gyermek dal«, de nem sok köze van a felhőn ugrándozó, bohókás álmodozáshoz, inkább a múlt század harmincas éveinek, mondjuk úgy, rögvalóságához van köze, változatos halálnemekkel, itt-ott Rejtő Jenő-i morbidsággal és egy fehér mellü (vagy testü) nővel, aki hiába vár. [...] A gyakran gyermekversszerzőként elkönyvelt, József Attilával épp egyidős Tamkó Sirató Károly munkásságáról, a dimenzionizmusról, a glogoizmusról, a költő Adyhoz, Illyéshez, úgy általában a Nyugathoz, illetve Kassákhoz fúződő viszonyáról Petőcz András doktori disszertációjában olvashat többet" (Forrás: https://444.hu/2014/12/10/szenzacios-irodalmi-lelet-kerult-elo-tengerecki-palt-leszurjakegy-kocsmaban). 
Bühler, Karl 1930. Die geistige Entwicklung des Kindes. Jena.

Dánielisz Endre 1981. Szendrey Zsigmond nagyszalontai évei. In: dr. Kós Károly - dr. Faragó József (szerk.): Népismereti dolgozatok. Kriterion Könyvkiadó, Bukarest, 202-18. Valamint: Erdélyi magyar adatbank, 202-218. http://adatbank.transindex.ro/html/alcim pdf12497.pdf.

Domokos Mariann - Gulyás Judit szerk. 2018. Az Arany család kéziratos mese- és találósgyüjteményének, valamint Arany László Eredeti népmesék címü müvének szinoptikus kritikai kiadása. MTA Bölcsészettudományi Kutatóközpont, Universitas Kiadó, MTA Könyvtár és Információs Központ, Budapest.

Faragó József - Fábián Imre (közzéteszi) 1982. Bihari gyermekmondókák. Kriterion Könyvkiadó, Bukarest.

Fónagy Iván 1990. Gondolatalakzatok, szövegszerkezet, gondolkodási formák. MTA Nyelvtudományi Intézete, Budapest. (Linguistica, Series C, Relationes, 3.)

Katona Imre 1979. Gyermekfolklór In: Ortutay Gyula (szerk.): Magyar folklór. Tankönyvkiadó, Budapest, 375-91.

Kiss Áron 2000. Magyar gyermekjáték-gyüjtemény. Holnap Kiadó, Budapest. (Reprint)

Kodály Zoltán 1993. Magyar zene, magyar nyelv, magyar vers. Válogatta, szerkesztette: Vargyas Lajos. Szépirodalmi, Budapest.

Marinov Iván 2017. Tényleg az égboltra gondoltak eredetileg a csigabigás mondókában a tủz helyett? http://www.urbanlegends.hu/2017/11/csiga-biga-mondoka-az-eg-a-hazad-idekiegbolt/.

N. Tóth Ida 2001. Kodály Zoltán nagyszalontai gyüjtése. Magyar Nemzet 2001. október 15. Valamint: https://magyarnemzet.hu/archivum/kulturgrund/kodaly-zoltan-nagyszalontaigyujtese-4628609/.

Sommerfelt, Alf 1974. A nyelv eredete. Elméletek és hipotézisek. In: A nyelv keletkezése. A bevezető tanulmányt írta és a kötetet összeállította: Papp Mária. Kossuth Könyvkiadó, Budapest.

Szendrey Zsigmond - Kodály Zoltán szerk. 1924. Nagyszalontai gyüjtés. Kodály Zoltán közreműködésével szerk.: Szendrey Zsigmond. Kisfaludy Társaság, Budapest.

Sebestyén Gyula, 1924. A nagyszalontai gyüjtésről [elöszó]. V-XV. In: Szendrey-Kodály szerk. 1924.

Szászi Éva 1943. Az önkéntelen rajzolgatásról. Dolgozatok a Kir. Magy. Pázmány Péter Tudományegyetem Philosophiai semináriumából 59. Révai Irodalmi Intézet nyomdája, Budapest.

Szathmári István főszerkesztő 2008. Alakzatlexikon. A retorikai és stilisztikai alakzatok kézikönyve. Tinta Könyvkiadó, Budapest.

Viski Károly 1919. Arany népe. Arany tárgyi néprajzának vázlata. Az Arany Emlékegyesület kiadása. Nagyvárad.

Viski Károly 1941. Életrajzi vázlat. Néprajzi Múzeum, Ethnológiai Adattár 10191. Budapest.

Voigt Vilmos 1975. Kishegyesi fonorejtvények. (Értelmetlen szövegek értelmezése.) A Hungarológiai Intézet Tudományos Közleményei VII/23-24: 169-87.

\section{Balázs Géza \\ egyetemi tanár}

ELTE BTK Mai Magyar Nyelvi Tanszék

Partiumi Keresztény Egyetem

https://orcid.org/0000-0003-3440-2959 


\section{SUMMARY}

Balázs, Géza

\section{What Children's Rhymes from Bihar reveal}

The world and world view of nursery rhymes encompass the universe of nature and society, and constitute a kind of "miniverse". Rhymes are live witnesses of the emergence of language and an integral part of language acquisition and foreign language learning today. They encapsulate ancient rites and primeval experience of mankind. Semiotic and anthropological linguistic analysis is able to reveal human history in a spiritual or magic sense that is hidden in nursery rhymes. The paper gives a detailed account of the tradition of folk lore collection that started in the wake of János Arany's cult in Nagyszalonta and later in Bihar County. It shows possibilities of interpretation of nursery rhymes, their structural and functional traits, and the world view that emerges from them.

Keywords: nursery rhyme, Bihar, Nagyszalonta, Zoltán Kodály, recital, repetition, zoomorphism, nonsense text. 